\title{
Intercultural communication: English dominance
}

\author{
Natalya Vladimirovna Chernyishkova ${ }^{{ }^{*}}$, Daria Valerievna Sukhorukova ${ }^{1}$, and Marina \\ Vadimovna Aroshidze ${ }^{2}$ \\ ${ }^{1}$ Financial University under the Government of the Russian Federation, Department of Foreign \\ Languages and Intercultural Communication, Moscow, Russia \\ ${ }^{2}$ Batumi Shota Rustaveli State University, Department of Slavic Studies, Batumi, Georgia
}

\begin{abstract}
The importance of intercultural communication in today's globalised world is undeniable. Scholars from different countries have contributed to the development of this field and created educational materials - textbooks on intercultural communication devoted to classifications and features of different cultures - and textbooks on foreign languages that include exercises devoted to developing intercultural skills in everyday and professional contexts. Teachers of foreign languages are making an effort to use the available materials that provide a wide outlook on various cultures and help students prepare for being a part of intercultural community. However, there is an evident shortage of such materials in languages other than English. The article provides the results of the analysis of online sources that demonstrates that the majority of available resources that are in any way connected with intercultural communication are in English. The article dwells on the reasons for English dominance in intercultural communication study and suggests a global effort as a solution. Whether we are looking at textbooks purely on intercultural communication or foreign language learning resources, it is important to understand that the English language cannot be the only medium of intercultural competence formation - other languages can and should be a prism through which intercultural communication is studied.
\end{abstract}

Keywords: intercultural communication, intercultural competence, textbooks, educational materials, skills, foreign language learning

\section{Introduction}

Intercultural communication has become one of the integral parts of acquiring foreign languages regardless of the initial purpose - educational or professional. Today any person working in an intercultural context understands the value that comes with understanding representatives of other cultures not only in terms of their language but also in terms of their cultural background [1]. A person who can successfully communicate with people from other cultures becomes a competitive specialist in the labour market [2]. Such an

* Corresponding author: nvchernvishkova@fa.ru 
employee will easily put a line between his/her culture and the other one, while also appreciating both similarities and differences between them [3].

When it comes to the term itself, "intercultural communication" can be confused with "cross-cultural communication", and these two terms are often used interchangeably. However, it seems to be a misconception that may be connected with only one term existing, for example, in French - "interculturel" [4]. In her article, Susan Fries, an Assistant Professor in the Département Langues et Formation Humaine at Institut National des Télécommunications in Evry, states that there cannot be any confusion about the English terms. "Cross-cultural" refers to something that is connected with several cultures, while "intercultural" - attention to the prefix 'inter' - presupposes interaction. This article looks at intercultural communication, and only this term has been analysed throughout the study.

The objective of the article is to study the availability of textbooks and educational materials on intercultural communication in different languages. We presuppose that there is a lack of such materials in languages other than English and attempt to identify possible reasons for this and look at what can be done to change it.

\section{Methods}

Being an important aspect of teaching foreign languages intercultural communication tends to be the subject of various textbooks and educational materials [5]. However, based on the personal experience of foreign language or intercultural communication classes at the university we can state that there is an evident shortage of educational materials in different languages excluding English. To analyse the actual situation we have studied the online sources - two book databases and an online shop: ISBN Database [6], Elsevier [7] and Amazon [8]. ISBN Database is a large collection of book data where one can do the search using ISBN, title, author, or publisher. It includes over 27 million ISBNs. Elsevier is a publishing company that grants access to various publications. Amazon is an online shopping platform that is available worldwide and can make a delivery to most countries. The study of the number of textbooks or other materials on intercultural communication was based on the search of the key words 'intercultural communication' and the specified language. The results for books based on these key words are presented in Table 1.

Table 1. Key words 'intercultural communication'.

\begin{tabular}{|c|c|c|c|}
\hline & ISBN Database & Elsevier & Amazon \\
\hline Overall & 10,000 & 5,654 & Over 3,000 \\
\hline English & 10,000 & 5,566 & Over 1,000 \\
\hline French & 1292 & 19 & - \\
\hline German & 1507 & 1 & 65 \\
\hline Spanish & 230 & 61 & 50 \\
\hline Chinese & - & - & 91 \\
\hline Russian & - & - & 19 \\
\hline Italian & - & - & 9 \\
\hline Japanese / Korean & - & - & 17 \\
\hline
\end{tabular}

\section{$3 \quad$ Results}


The issue of the lack of publications, may it be books, textbooks, articles or anything else, becomes undeniable if one looks at online databases or shops. The analysis of such sources has shown that the dominance of English as the language of intercultural studies is uncontestable. Table 1 reflects the current situation with books on intercultural communication; the figures are given as a result of search through these websites based on the key words 'intercultural communication' and the language criterion. The number of books available in English is much higher than for other languages.

ISBN database can offer more than 10,000 materials on intercultural communication, the majority of which are in English. The site does not even state the exact number of English sources and just shows the same figure $-10,000$. However, more attention should be paid to the figures representing educational materials in other languages - French and German figures are still quite impressive, while the same cannot be said about Spanish.

The search for 'international communication' on Elsevier showed that the number of books amounts to 5,665, 98\% of which are in English - a staggering figure compared to 19 - in French, 1 - in German and 61 - in Spanish. It should be noted that both ISBN database and Elsevier show search results for English, French, German and Spanish but not so much for other languages. Elsevier can offer two books in Dutch and one - in Portuguese.

The total number of books connected with 'intercultural communication' available on Amazon is more than 3,000 - more than 305 of them are in English. We are able to present figures for several languages, including Chinese, Italian, Russian, Japanese and Korean. Interestingly, there is no result for books connected with 'intercultural communication' in French.

It should be noted that we have not eliminated books or other educational materials from the search based on their topic. The presented results are purely for the key words 'intercultural communication' - ISBN database specifies that the search is done for books, on Elsevier we have chosen 'books' category, excluding journals, and on Amazon the search starts from choosing the section 'Books' and then entering the key words and the language. Therefore, the number of books that deal directly with intercultural communication can be even lower.

\section{Discussion}

The importance of creating textbooks of high quality is undeniable, and when it comes to textbooks on intercultural communication authors should understand how to choose the right approach to writing them. Safonova in her paper on intercultural communication educational materials outlines five methodological principles of such work:

1) correlation between global and national,

2) priority of intercultural dominant idea,

3) creation of problem-oriented methodological environment,

4) orientation towards professionally relevant bilingualism,

5) a multiple-level system [9].

These principles reflect how an author can work out an effective strategy for creating educational materials on intercultural communication; however, looking at textbooks that are currently available we can clearly see the dominance of the English language. The analysis of the online sources proves that English is perceived as the preferred language for creating textbooks or other educational materials on intercultural communication. On the one hand, it may seem logical since English is the "global" language - many people know it, take classes in it and use it for professional reasons [10]. Companies all over the world are becoming more culturally sensitive because of the foreign competition, and English is 
the language that serves as the basis for acquiring intercultural competence [11]. On the other hand, we live in the era of globalisation - cultures are intertwining, borders are being eliminated, that is why we are studying intercultural communication and aspiring to gain intercultural competence, and yet, to do that we mostly have to rely on educational materials in English.

The lack of educational materials in different languages may be also connected with the origin of scholars who have been studying intercultural communication because they are the ones who have made this topic widely known and contributed to people studying it more thoroughly. Most of them are Americans, for instance, Stella Ting-Toomey, William B. Gudykunst, Janet M. Bennett, Milton J. Bennett, Fred E. Jandt and Edward T. Hall who is considered one of the "founding fathers" of the study of intercultural communication [12]. We should mention one Englishman - Richard D. Lewis - and Young Yun Kim - a scholar who was born and raised in Seoul, Korea but currently works at the University of Oklahoma, Norman. Last but not least are Dutch theorists - Fons Trompenaars and, most importantly, Geert Hofstede. Based on the fact that most of these academics' native language is English or they use it in their professional life, it is possible to assume that the dominance of the English language in educational materials on intercultural communication is logical. These scholars have created a theoretical basis for studying intercultural communication, their input is invaluable but it would be wrong to assume that this field is not developing [13]. Nowadays the concept of intercultural communication is well known and studied by people in different countries. People will fail if they rely only on the paradigms and frameworks outlined by Hall or Hofstede; people need to move further, to look not only for 'standard' examples of culture-induced behaviour but for anything that can be attributed to it [14]. Therefore, there is a need for more educational materials on this subject in different languages that would reflect what is happening in intercultural communication today and how it becomes more and more connected with other disciplines that use theories developed within the framework of intercultural communication [15].

Intercultural communication is now an integral part of teaching foreign languages, as we have understood that without proper skills a person cannot successfully communicate with representatives of other cultures. People may learn to speak a language but if they do not try to comprehend how culture influences the whole process of communication, they will fail to achieve the desired results, especially in professional context [16]. This is why it is essential for teachers to include intercultural aspect in their classes. Without proper educational materials it may be challenging because teachers often work with representatives of their own culture, and to dive into the intricacies of other cultures they do need books or other sources to rely on. Plus, it is important to develop new ways of teaching intercultural communication using the Internet as a way of interacting with representatives of other cultures, but this should be done properly through creating methodological approaches to this type of activity [17]. The opportunities of developing intercultural competence presented by the Internet have not been studied or discussed enough yet [18]. This requires a global effort that will lead to success thanks to an increasing number of online educational platforms. We can already speak about the integration of different online services into traditional approach, for instance, Google services have proved their effectiveness for teaching foreign languages [19]. Now the global community of teachers and learners need to take a step further and apply this specifically for improving intercultural skills.

The development of the world around us leads to changes in how people communicate, especially those who come from different cultures. People aspire to share their values and experiences with others and want to learn more about other cultures to understand them 
better [20]. Textbooks tend to describe certain frameworks of behaviour that may become partially stereotypical. It is a teacher's job to eliminate any type of stereotype formation about other cultures. If there are no stereotypes, no prejudice, individuals get a chance to become more interculturally conscious [21]. To achieve this, a teacher needs to look for educational materials that would follow certain standards, however, in reality to find one "ideal" textbook is difficult. That is why teachers have to analyse all the existing textbooks and choose the ones that follow these criteria:

1) sociocultural saturation - including enough information on various topics connected with intercultural communication;

2) system - achieving transparency of the presented information;

3) motivation - taking into account the age and professional needs of the students;

4) content - connecting the texts and other material to the professional field;

5) contrast - showing similarities and differences between cultures, which allows students to understand other cultures better;

6) information - including different viewpoints on the topics covered in the textbook,

and all this should be supported by exercises that lead to the formation and development of intercultural skills and competence [22].

If educational materials are chosen wisely, they will help to debunk stereotypes that are formed about most cultures, thus creating the basis for strong international communication skills [23].

Textbooks on intercultural communication should also include examples of 'realia' elements of cultures that reflect the national character and historic events of a certain people because they will allow students to dive into another culture through words and things that constitute it on linguistic and mental levels [24]. In addition, the understanding of specific elements of a certain culture that can be partially connected with the language itself is also of utmost importance. For instance, in professional contexts people can face difficulties connected with different classifications of businesses [25]. The lack of understanding, in this case, may lead to negative consequences for both sides of professional intercultural communication.

\section{Conclusion}

The analysis of online sources has demonstrated the lack of educational materials on intercultural communication in different languages. The majority of textbooks are written in English because it is a "global" language and a native language for most scholars who have studied intercultural communication.

Creating educational materials in different languages is a necessity predetermined by intercultural communication itself - it should be studied through the prism of various languages, not only English. French, German, Spanish, etc. textbooks on intercultural communication will be of great importance for different specialists, including teachers of foreign languages.

Communicative language teaching that is quite popular today presupposes understanding other cultures [26]. Therefore, it may be more reasonable to create textbooks and educational materials on foreign languages with inclusion of intercultural aspects rather than focus on writing a textbook purely on intercultural communication. It is necessary to include a balanced cultural representation into the created language textbooks incorporating not only the aspects of a local culture [27]. By focusing on different cultures and looking for ways to explain them to students, educators face a challenge connected with the 
structure of these textbooks [28]. For example, neologisms should be seen as one of the integral aspects of developing language and culture [29]. They are directly connected with the formation of linguistic and intercultural competences. Therefore, exercises aimed at developing skills dealing with neologisms in business discourse should lead to acquiring knowledge about a specific language system and culture [30].

Currently, TESOL (Teaching English for Speakers of Other Languages)-textbooks include information on different cultures but it cannot be considered enough to help students develop intercultural competence and fully understand how to communicate effectively with representatives of other cultures [31]. To show a better aptitude for intercultural communication students should face concrete situations that may happen between specific groups, as it can provide insight into why they need intercultural competence in today's diverse world (professionally and globally) [32]. The emphasis on the cultural background and respect towards cultural heritage can be beneficial for students in terms of unique experiences they gain during the learning process [33].

It does not matter whether we are talking about textbooks on intercultural communication or textbooks on foreign languages that incorporate information on various cultures, the topicality of such educational materials is evident, and scholars around the world should become a part of a global effort to form students' outlook on other cultures through studying intercultural communication not only in English and acquiring intercultural competence while learning different languages.

\section{References}

1. E.A. Fedorova, et al., Int J Eng Adv Tech, 9(1), $4532-4535$ (2019).

https://doi.org/10.35940/ijeat.A1785.109119

2. I.I. Klimova, G.V. Klimova, S.A. Dubinka, XLinguae, 12(1), 207-218 (2019). https://doi.org/10.18355/XL.2019.12.01.16

3. E.A. Zueva, Higher Edu Today, 3, 43-47 (2019). https://doi.org/10.25586/RNU.HET.19.03.P.43

4. S. Fries, J TESOL France, 10, 5-17 (2003)

5. B. Urhan, Intercultural Communication: A Literature Review, in Metin I. (ed), İnönü Üniversitesi İletişim Fakültesi, 139-151 (2016)

6. ISBNdb: The World's largest book database. Accessed on: September 24, 2021. [Online]. Available: https://isbndb.com

7. Elsevier Wordmark. Accessed on: September 24, 2021. [Online]. Available: https://www.elsevier.com

8. Amazon. Accessed on: September 24, 2021. [Online]. Available: https://www.amazon.com/

9. V.V. Safonova, Moscow Univ Bul. Ser 19. Ling Intercult Comm, 2, 65-76 (2018)

10. M.A. Antonyan, Pedagogy, 9, 87-95 (2019)

11. F. Patel, M. Li, P. Sooknanan, Intercultural communication: Building a global community (2011). https://doi.org/10.4135/9781446270318

12. M. Baba, J App Behav Sci, 31, 117-118 (1995). https://doi.org/10.1177/0021886395312001 
13. T.N. Omelyanenko, Problems of intercultural communication in teaching foreign languages, Language and culture in bilingual educational space, in Materials of the III International Scientific and Practical Conference, 155-160 (2017)

14. M. Nguyen-Phuong-Mai, Intercultural Communication. An Interdisciplinary Approach: When Neurons, Genes, and Evolution Joined the Discourse (Amsterdam University Press B.V., Amsterdam 2017)

15. S.M. Croucher, S. Mélodine, R. Diyako, Comm Res Prac 1:1, 71-87 (2015). https://doi.org/10.1080/22041451.2015.1042422

16. T.V. Sedova, Integration of intercultural communication into teaching foreign languages as a factor of forming a successful professional, Theory and Practice of Teaching Languages and Cultures: Philosophical and Methodological Aspects, in Materials of the II International Scientific and Practical Conference, 48-59 (2017)

17. Lugovaya AA, Selfmanagement, 2(24), 54-60 (2021)

18. V.V. Safonova, Eurasian Forum, 1(6), 6-20 (2014)

19. E.V. Savchenko, Izv: Herzen Univ J Human Sci, 199, 99-107 (2021). https://doi.org/10.33910/1992-6464-2021-199-99-107

20. O.A. Azarova, et al., J Envir Manag Tourism, 10(6(38)), 1376-1381 (2019). https://doi.org/10.14505/jemt.v10.6(38).20

21. M.Z. Altan, Bashkortostan Pedag J, 2, 133-137 (2011)

22. T.M. Yozhkina, N.N. Sergeeva, Bul Ural Branch Rus Acad Edu, 123-127 (2006)

23. N.A. Kozlovtseva, N.N. Tolstova, Bakhtiniana, 14(1), 82-113 (2019). http://dx.doi.org/10.1590/2176-457338362

24. T.Y. Samuilik, The Rus Lang Cult Transl, 1, 483-493 (2017)

25. E.A. Zueva, Z. Kralova, Int J App Ex Phys, 8-2, 317-323 (2019). https://doi.org/10.30472/ijaep.v8i2.1.566

26. E.V. Morozova, Hist App Comm Lang Teach, 10-2, 153-158 (2020)

27. H. Manzoor, A. Asma, S. Umrani, J Edu Soc Sci, 13(2), 1-9 (2019)

28. V.V. Levchenko, A.I. Oldmixon (Lager), T.N. Lubimova, Pedag Sci, 3(96), 39-46 (2019)

29. A.S. Mirzamova, Quest Theory Prac, 13(6), 284-290 (2020). https://doi.org/10.30853/filnauki.2020.6.5

30. E.M. Galishnikova, S.N. Khalevina, O.V. Meshcheryakova, XLinguae, 10(4), 357-366 (2017). https://doi.org/10.18355/XL.2017.10.04.29

31. E.S. Purgina, E.I. Purgina, Pedag Edu Rus, 11, 31-36 (2015)

32. A.C. Kelly, Honors Prog Theses, 325 (2018)

33. Y.B. Novikova, et al., XLinguae, 10(4), 369-380 (2017). https://doi.org/10.18355/XL.2017.10.04.30 